\title{
ЛІСІВНИЧО-ТАКСАЦІЙНА ХАРАКТЕРИСТИКА НАСАДЖЕНЬ У ВОЛЬЄРАХ ЦЕНТРАЛЬНОГО ПОЛІССЯ
}

Досліджено лісівничо-таксаційну структуру лісових насаджень вольєрів Центрального Полісся. У межах регіону функціонує 20 вольєрів загальною площею 639,5 га. Встановлено, що 74,7 \% (477,6 га) їх площі становлять лісові насадження. У межах вольєрів виділено 13 типів лісу. Боровий комплекс представлений тільки $\mathrm{A}_{2} \mathrm{C}(0,2$ га). У суборових умовах серед чотирьох типів лісу $\left(\mathrm{B}_{2}\right.$ ДС, $\mathrm{B}_{3}$ ДС, $\mathrm{B}_{4}$ ДС, $\mathrm{B}_{5}$ БС) абсолютна перевага належить $\mathrm{B}_{2} Д \mathrm{C}-95,3$ га, або 14,9\% від загальної площі лісових насаджень. Сугруди представлені 8 типами лісу. Переважаючими $є \mathrm{C}_{2}$ ГДС (116,6 га) та С $\mathrm{C}_{3}$ ГДС (100,1 га). Ще 3 типи лісу займають великі площі, а саме: $\mathrm{C}_{2}$ ГД (33,9 га), $\mathrm{C}_{3}$ ГД (55,9 га) та $\mathrm{C}_{4}$ Влч (25,0 га). У вольєрах переважають мішані насадження 56,1% (268,1 га). Серед чистих найбільшу площу займають соснові насадження - 123,5 га, 3 яких 82,4 га належить типу лісу В 2 ДС. У вольєрах переважають пристигаючі насадження (48,3 \%, або 230,8 га). На території вольєрів значна площа перестійних насаджень (36,3 га, або 7,6 \%). Середня повнота становить 0,71. Виділено шість класів бонітету (від $\mathrm{I}^{\mathrm{b}}$ до IV), за якими зростають деревостани у вольєрах. Найбільші площі займають I ${ }^{\mathrm{a}}(100,7$ га), I (168,5 га), і II (156,8 га). Серед мішаних насаджень переважають пристигаючі деревостани (53,7 \%, або 143,9 га), молодняки вкривають 12,8 \% площ (34,4 га), середньовікові - 17,1 \% (45,8 га). Площа мішаних перестійних насаджень (25,4 га або 9,5 \%) більша за стиглі (18,6 га, або 6,9 \%). Повнота мішаних насаджень змінюється від 0,46 до 1,0. Класи бонітету змінюються від I до ІІІ. Найпоширенішими кла-

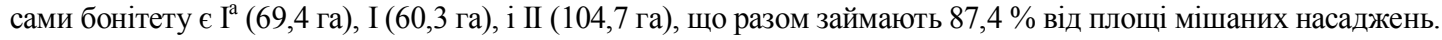

Ключові слова: тип лісорослинних умов; тип лісу; склад; група віку; повнота; клас бонітету.

Вступ. Розведення тварин на обмеженій території дає можливість досконалішого контролю за популяцією, що веде до значного зростання чисельності та якості поголів'я. Натомість, стрімке збільшення мисливської фауни неодмінно веде до посилення впливу з боку тварин на лісові насадження. Особливо це актуально для невеликих вольєрів, де через обмеженість площі дуже важко зберегти лісові насадження від поступової деградації. Такі процеси є невідворотними супутниками вольєрів. Тому щоразу під час створення нових вольєрів потрібно проводити глибокий аналіз відповідності площі вольєрів, видового і чисельного складу тварин у них та лісівничо-таксаційних характеристик лісових насаджень.

Наразі відомості про лісівничо-таксаційну характеристику лісових насаджень у вольєрах мають епізодичний характер і не розкривають загальної картини. Зазвичай автори обмежуються загальними фразами про лісові насадження. Так, чи не єдине згадування про лісові насадження у вольєрах Центрального Полісся знаходимо у М. Н. Свтушевського (Yevtushevskyi, 2009, 2012). Він зазначає, що вольєр ДП "Баранівське ЛМГ" (56,2 га) розташований переважно у соснових жердняках із підростом липи та крушини. Подібний опис автор дає i вольєру площею близько 30 га у Констянтинівському лісництві ДП "Сарненське ЛГ" (Західне Полісся). У межах Полісся детальніші таксаційні характеристики ок- ремих лісових насаджень можемо знайти для вольєрів ТзОВ "Явір Плюс" (Західне Полісся) (Khoietskyi et al., 2014) та ДО "Резиденція "Залісся" (Чернігівське Полісся) (Kaminetskyi, Babich \& Smahol, 2011).

Саме відсутність такої інформації спонукало нас провести лісівничо-таксаційну характеристику лісових насаджень вольєрів Центрального Полісся, адже їі брак гальмує розроблення довготермінових програм збереження лісових насаджень й підвищення продуктивності лісів в умовах напіввільного утримання тварин.

Мета роботи - з'ясувати лісівничо-таксаційні показники лісових насаджень вольєрів Центрального Полісся. Для досягнення поставленої мети потрібно проаналізувати лісовпорядні матеріали наявних об'єктів напіввільного утримання ратичних тварин на території Центрального Полісся.

Матеріали та методи дослідження. Розташування вольєрів встановлено у польових умовах на основі Проектів організації і розвитку мисливського господарства користувачів мисливських угідь Центрального Полісся. За основу для проведення лісівничо-таксаційного аналізу лісових насаджень взято повидільні таксаційні описи лісогосподарських підприємств Житомирського обласного управління лісового та мисливського господарства та Житомирського обласного комунального агролісогосподарського підприємства "Житомироблагроліс".

\section{Інформація про авторів:}

Кратюк Олександр Леонідович, канд. біол. наук, доцент, кафедра експлуатації лісових ресурсів. Email: deneshi_ks@ukr.net; https://orcid.org/0000-0002-2661-8074

Цитування за ДСТУ: Кратюк О. Л. Лісівничо-таксаційна характеристика насаджень у вольєрах Центрального Полісся. Науковий вісник НЛТУ України. 2019, т. 29, № 3. С. 36-38.

Citation APA: Kratiuk, O. L. (2019). Forest taxation characteristic of tree stands in the enclosures of Central Polissya. Scientific Bulletin of UNFU, 29(3), 36-38. https://doi.org/10.15421/40290307 
Результати дослідження та їх обговорення. Територія Центрального Полісся згідно з комплексним лісогосподарським районуванням відповідає Центральнополіському лісогосподарському району Західно- і Центральнополіського округу лісогосподарської області Полісся (Hensiruk, 2002). Для цього округу характерне домінування суборів (49 \% лісових земель). На сугруди припадає $32 \%$, а на бори - $17 \%$ лісових земель (Savuschyk \& Popkov, 2008).

Загальна площа лісового фонду Центрального Полісся становить 749772,6 га. Найпоширенішим типом лісорослинних умов $\epsilon$ вологий субір, що займає 152517,3 га, або $22 \%$ вкритих лісовою рослинністю земель. На сьогодні переважають середньовікові та пристигаючі насадження, відповідно 45,7 та 19,4 \% (Krasnov \& Zhukovsky, 2013). Наразі на території Центрального Полісся функціонує 20 вольєрів площею від 1,5 га (ДП "Народицьке СЛГ") до 228,0 га (СФГ "Земля Полісся"), що загалом становить 639,5 га. Встановлено, що 74,7 \% (477,6 га) їх площі становлять лісові насадження.

За типами лісорослинних умов переважають сугруди, частка яких сягає більше половини загальної площі лісових насаджень вольєрів і становить 70,14\%, або 335,0 га. Частка суборів становить $29,82 \%(142,4$ га). Практично немає борів. Їх площа всього 0,2 га.

За гігротопами переважають свіжі $(51,51 \%)$ та вологі $(38,23 \%)$ місцезростання. За рівнем вологості серед суборів найпоширеніші свіжі умови (19,95\%), вологі становлять $5,13 \%$, мокрі - по 4,12\%, а сирих - тільки 2,9 га $(0,61 \%)$. Натомість у сугрудах за рівнем вологості переважають вологі $(33,10 \%)$ та свіжі $(31,51 \%)$ умови. Частка сирих становить 5,53 \% від загальної площі лісових насаджень.

У межах вольєрів виділено 13 типів лісу. Боровий комплекс представлений тільки $\mathrm{A}_{2} \mathrm{C}$. У суборових умовах серед чотирьох типів лісу $\left(\mathrm{B}_{2}\right.$ ДС, $\mathrm{B}_{3}$ ДС, $\mathrm{B}_{4}$ ДС, $\mathrm{B}_{5} \mathrm{БC}$ ) абсолютна перевага належить $\mathrm{B}_{2}$ ДС - 95,3 га, або 14,9 \% від загальної площі лісових насаджень. Сугруди представлені 8 типами лісу $\left(\mathrm{C}_{2}\right.$ ГД, $\mathrm{C}_{2}$ ГДС, $\mathrm{C}_{3}$ ГД, $\mathrm{C}_{3}$ ГДС, $\mathrm{C}_{3} Д Г, \mathrm{C}_{4} Г Д С, \mathrm{C}_{4} Д С О, \mathrm{C}_{4}$ Влч). Переважаючими є $\mathrm{C}_{2}$ ГДС (116,6 га) та $\mathrm{C}_{3}$ ГДС (100,1 га). Ще 3 типи лісу займають великі площі, а саме: $\mathrm{C}_{2}$ ГД (33,9 га), С $\mathrm{C}_{3}$ ГД $\left(55,9\right.$ га) та $\mathrm{C}_{4}$ Влч $(25,0$ га).

На території Центрального Полісся площа хвойних насаджень становить $60,0 \%$ від вкритих лісовою рослинністю земель, твердолистяних - 18,8 \%, а м'яколистяних - 21,2\%. (Krasnov \& Zhukovsky, 2013). Серед хвойних насаджень переважають чисті соснові, які становлять $71,0 \%$ від їх загальної площі і мають запас 78910,67 тис. м³ 21116,63 тис. м³. За групами віку переважають середньовікові насадження. Їх частка становить близько $45,0 \%$ і становлять 169724,3 га; молодняки вкривають 21,0 \% площ (79862,6 га), пристигаючі сосняки - 22,0 \% (83519,7 га); стиглі насадження зростають на площі 41783,8 га і становлять $11 \%$ від загальної площі. Повнота соснових насаджень змінюється від 0,3 до 1,2 . Найпоширенішою повнотою соснових насаджень $є 0,7 \mathrm{i}$ 0,8 , що становить $76,0 \%$. Середня повнота становить 0,77 . Спостерігаються значні коливання класу бонітету насаджень від $\mathrm{I}^{\mathrm{d}}$ до $\mathrm{V}^{\mathrm{b}}$, що пояснюють їх зростанням у різних типах лісорослинних умов. Найпоширенішими класами бонітету є I ${ }^{\mathrm{a}}$, I і II, що займають 85,0 \% від усіх насаджень. Середній клас бонітету - I,4 (Zhukovsky \& Zborovska, 2013).
У вольєрах переважають мішані насадження 56,1\% (268,1 га) 3 домінуванням сосни звичайної (Pinus sylvestris L.) та дуба звичайного (Quercus robur L.) (рис. 1). Серед чистих найбільшу площу займають соснові насадження - 123,5 га, з яких 82,4 га належить типу лісу $\mathrm{B}_{2}$ ДС. Площі чистих дубових та березових насаджень становлять відповідно 36,3 та 32,4 га.

На відміну від Центрального Полісся загалом, у вольєрах переважають пристигаючі насадження (рис. 2). Ïх частка становить 48,3 \% (230,8 га), середньовікові вкривають $18,6 \%$ площ (88,9 га), а стиглі - $11,1 \%$ $(53,1$ га). На території вольєрів - велика площа перестійних насаджень (36,3, га або 7,6 \%).

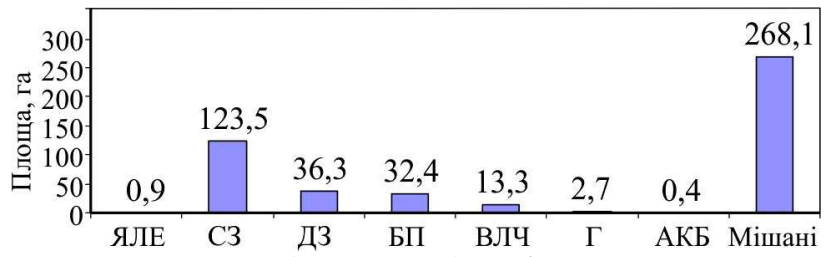

Рис. 1. Площа чистих (за породами) та мішаних насаджень у вольєрах Центрального Полісся, га

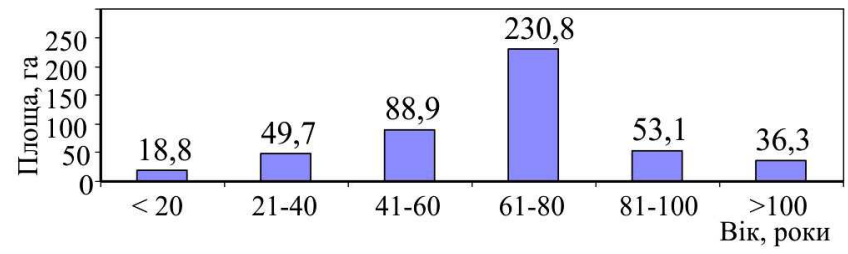

Рис. 2. Вікова структура лісових насаджень у вольєрах Центрального Полісся, га

Повнота насаджень змінюється від 0,46 до 1,0 . Середня повнота становить 0,71 . Чим щільніше змикаються крони дерев, тим менше світла і тепла проникає до грунту, тим слабкіше розвиваються підлісок та живий надгрунтовий покрив, а звідси - і різниця в запасах кормів для мисливських тварин. Тому у насадженнях з високою повнотою, особливо жердняках, з одного боку, легко сховатися та помітити наближення небезпеки, а 3 іншого - важко знайти достатню кількість деревно-чагарникових кормів. Деревостани у вольєрах зростають за шістьма класами бонітету (від $\mathrm{I}^{\mathrm{b}}$ до IV). Найпоширенішими класами бонітету є I I $^{(100,7}$ га), I (168,5 га), i II (156,8 га), що разом займають 89,2 \% від площі лісових насаджень (рис. 3).

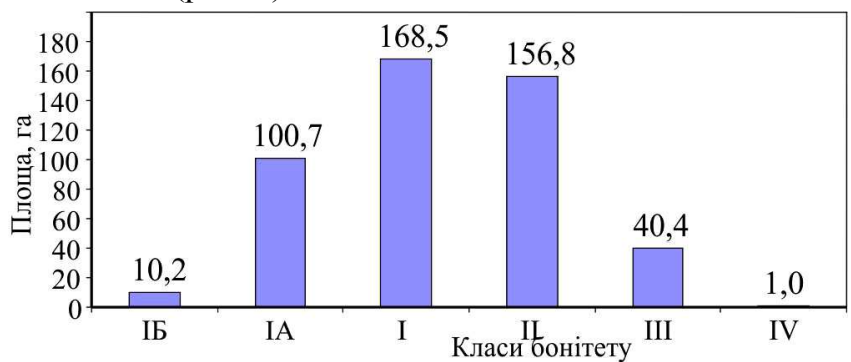

Рис. 3. Розподіл лісових насаджень у вольєрах Центрального Полісся за класами бонітету, га

Серед мішаних насаджень, які домінують у вольєрах, також переважають пристигаючі деревостани (рис. 4). Їх частка становить 53,7 \%, або 143,9 га, молодняки вкривають $12,8 \%$ площ $(34,4$ га), середньовікові 17,1 \% (45,8 га). На території вольєрів площа мішаних перестійних насаджень (25,4 га, або 9,5\%) більша за стиглі (18,6 га, або 6,9 \%). Повнота мішаних насаджень змінюється від 0,46 до 1,0, а середня становить 0,71. Де- 
ревостани зростають за I $\mathrm{I}^{\mathrm{b}}$-III класами бонітетів. Найпоширенішими $\epsilon I^{\mathrm{a}}(69,4$ га), I (60,3 га), i II (104,7 га), що разом займають 87,4 \% від площі мішаних насаджень.

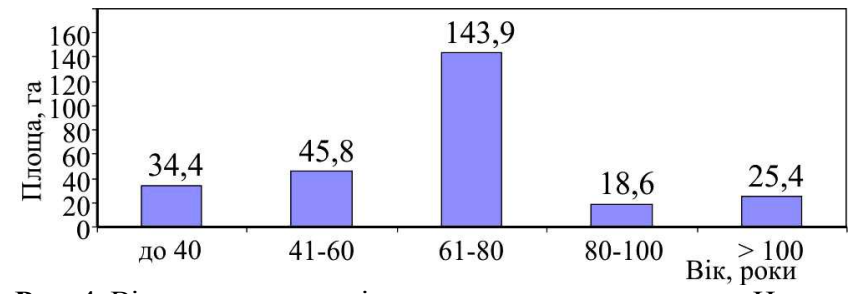

Рис. 4. Вікова структура мішаних насаджень у вольєрах Центрального Полісся, га

Наявність підросту та підліску, його густота та стан у вольєрах $\epsilon$ індикатором інтенсивності впливу мисливської фауни на лісові насадження. Згідно з таксаційними описами підріст та підлісок присутній на площі у 113,1 га. Це близько 23,7 \% від загальної площі лісових насаджень. Середня зімкнутість становить 0,4 . У підліску переважає крушина ламка (Frangula alnus Mill.).

Висновки та перспективи подальших досліджень. У вольєрах переважають мішані насадження 3 домінуванням Pinus sylvestris та Quercus robur, які за кормовими та захисними властивостями, в регіоні досліджень, $є$ чи не найпридатнішими для функціонування популяції мисливської фауни у напіввільних умовах. Близькими до них можна вважати чисті дубові насадження, проте їх поширення у вольєрах обмежене. Для вольєрів притаманні великі площі чистих соснових насаджень, що відображає загальні тенденції домінування соснових монокультур у регіоні. Суборові типи лісу є досить бідними у кормовому плані. За групами віку у вольєрах переважають пристигаючі насадження. Тут також велика площа стиглих і перестійних деревостанів. 3 віком у таких насадженнях відбувається зрідження деревостану, що сприяє розвиткові підросту, підліску і рослин трав'яного покриву. Все це помітно збільшує запаси деревно-чагарникових та інших видів кормів. До того ж такі деревостани стійкіші до впливу на них мисливської фауни.

Загалом узагальнення знань про лісівничо-таксаційні показники лісових насаджень у вольєрах дасть змогу розробити рекомендації щодо невиснажливого ведення вольєрного мисливського господарства в лісах.

\section{Перелік використаних джерел}

Hensiruk, S. A. (2002). Lisy Ukrainy. Lviv: Ukrainski tekhnolohii. [In Ukrainian].

Kaminetskyi, V. K., Babich, O. H., \& Smahol, V. M. (2011). Ekolohichni ta hospodarski aspekty napivvilnoho rozvedennia dykykh kopytnykh (na prykladi spetsializovanykh pidpryiemstv Derzhavnoho upravlinnia spravamy Prezydenta Ukrainy). Kyiv: ZAT "Myronivska drukarnia". [In Ukrainian].

Khoietskyi, P. B., Skol'skyy, I. N., Pokhaliuk, O. M., \& Parenyuk, A. P. (2014). Ungulate animals impact on the tree-and-shrub vegetation underconditions of the game animal enclosure in Yavir Plus Limited liabilities company. Scientific Bulletin of UNFU, 24(9), 41-45. [In Ukrainian].

Krasnov, V. P., \& Zhukovsky, O. V. (2013). The structure of the forest fund of Zhytomyr Polissya. Scientific Bulletin of UNFU, 23(6), 27-35. [In Ukrainian].

Savuschyk, M. P., \& Popkov, M. J. (2008). Typological structure of forests in Ukrainian Polissya. Forestry and Forest Melioration, 113, 31-37. [In Ukrainian].

Yevtushevskyi, M. N. (2009). Pliamystyi olen (Servus nippon hertulorum Swinhoe, 1864) v Ukraini ta za yii mezhamy. Kyiv: Publishing House "Eko-inform". [In Ukrainian].

Yevtushevskyi, M. N. (2012). Myslyvski tvaryny Ukrainy na voli ta v volierakh. Cherkasy: Vertykal. [In Ukrainian].

Zhukovsky, O. V., \& Zborovska, O. V. (2013). The structure of pine plantations in Zhytomyr Polissya. Scientific Bulletin of UNFU, 23(3), 49-54. [In Ukrainian].

O. L. Kratiuk

Zhytomyr National Agroecological University, Zhytomyr, Ukraine

\section{FOREST TAXATION CHARACTERISTIC OF TREE STANDS IN THE ENCLOSURES OF CENTRAL POLISSYA}

The rapid increase of hunting fauna in the conditions of semi-free maintenance necessarily leads to an increase in the impact of animals on forest stands. This is especially true for small enclosures, where it is quite difficult to preserve forest stands from gradual degradation due to the limited area. Estimated survey units' descriptions of forest enterprises of Zhytomyr Regional Department of Forestry and Hunting and Zhytomyr Regional Communal Forestry and Agricultural Enterprise "Zhytomyroblagrolis" were taken as the basis for analyzing forest taxation of tree stands in the enclosures. There are 20 enclosures on the territory of Central Polissya with the area ranging from 1.5 ha (Narodnytske SE) up to 228 ha (Zemlya Polissya Peasant Farming) with the total number 639.5 ha. Forest stands are revealed to occupy $74.7 \%$ (477.6 ha) of their area. Thirteen forest types are peculiar for the enclosures. They are as follows: 1 in coniferous forest conditions $\left(\mathrm{A}_{2} \mathrm{C}\right)$, 4 in mixed coniferous forest conditions $\left(\mathrm{B}_{2} Д С, \mathrm{~B}_{3} Д С, \mathrm{~B}_{4} Д С, \mathrm{~B}_{5} Б \mathrm{C}\right)$ and 8 in mixed hardwood forest conditions $\left(\mathrm{C}_{2} Г Д, \mathrm{C}_{2} Г Д С, \mathrm{C}_{3}\right.$ ГД, $\mathrm{C}_{3}$ ГДС, $\left.\mathrm{C}_{3} Д Г, ~ \mathrm{C}_{4} Г Д С, \mathrm{C}_{4} Д С О, \mathrm{C}_{4}\right)$. In the enclosures maturing stands dominate ( $48.3 \%$ or $230.8 \mathrm{ha})$, mid-aged stands cover $18.6 \%$ of the area $(88.9 \mathrm{ha})$, and mature stands occupy $11.1 \%(53.1$ ha). Quite a large area is covered with overmature stands $(36.3$ ha or $7.6 \%$ ) on the territory of the enclosures. Stand stocking ranges from 0.46 to 1.0 , where average stocking is 0.71 . Stand quality in the enclosures is subdivided into six classes (from I to IV). The most widespread classes of stand quality are $\mathrm{I}^{\mathrm{a}}$ (100.7 ha), I (168.5 ha), and II (156.8 ha), that together occupy $89.2 \%$ of forest stand. Among the mixed stands prevailing in the enclosures, maturing stands dominate (53.7\% or 143.9 ha), young growth covers $12.8 \%$ of the area ( $34.4 \mathrm{ha})$, and the mid-aged stands area is $17.1 \%$ (45.8 ha). On the territory of the enclosures, the area of mixed overmature stands $(25.4$ ha or $9.5 \%)$ is larger than mature stands ( 18.6 ha or $6.9 \%)$. Mixed stand stocking is 0.71 . Tree stands grow according to $\mathrm{I}^{\mathrm{a}}$ (69.4 ha), I (60.3 ha), and II (104.7 ha) of stand quality which together accounts for $87.4 \%$ of the mixed stands area. The presence of young growth and undergrowth, their density and state in the enclosures is an indicator of the intensity of the impact of hunting fauna on the forest stand. According to the estimated survey units' descriptions, young growth and undergrowth are present on the area of 113.1 ha. It is about $23.7 \%$ of the total area of forest stands. The average canopy density is 0.4 . The domination of mixed stands, which are the most suitable for fodder and protective properties in the region for the functioning of the hunting fauna population, positively affects the animals in the enclosures. The generalization of knowledge about the forestry indicators of forest stands in the enclosures is to enable the development of recommendations for the non-exhausting hunting enclosure management in the forests. Therefore, whenever new enclosures are created, it is necessary to carry out a deep analysis of the location of the enclosures, the species composition and number of animals there, and the forest taxation indicators of forest stands.

Keywords: forest vegetation type; forest type; composition; age group; completeness; stand quality class. 